\title{
Ideological Tendencies of the Social Media Contents for Children
}

\author{
A. Aslı Sezgin \\ Department of Public Administration and Political Sciences, Osmaniye Korkut Ata University, Turkey
}

Copyright $(2016$ by authors, all rights reserved. Authors agree that this article remains permanently open access under the terms of the Creative Commons Attribution License 4.0 International License

\begin{abstract}
The term social media which was presented into our daily life by Web 2.0 technology and brought a new perspective on our social life habits is the issue which has been discussed broadly in recent years. Social media is composed of different categories such as making friendship and widening environment, social business networks, matchmaking network, graduation network and trademark social networks. Among these networks; Facebook has a large amount of user in Turkey. In Facebook social network in which people from every section can meet in a common network, political views can be shared as well. Children who are mostly influenced by mass media and today especially by new media can learn values and views about political system through new media. Facebook is the universe of this study due to being the most common social network in our country, the sample of study was 4 community pages which were created with the keyword of child in Facebook social network and with the content for children. Facebook community pages which are included in children category will be analyzed with the method of semiotic analysis considering their visual richness. Ideological trends of these pages created for the children will be discussed through this method.
\end{abstract}

Keywords Child, Facebook, Ideology, Social Media, New Media

\section{Introduction}

Internet technology, claiming its place in history as an important location in the turning points of the human life, has a robust role for information revolution to reassess the fundamental nature of the humankind and question its place in the universe. Internet technology, which has been developed by the Project Research Agency affiliated with United States Department of Status to make connection with remote places, has been started to be used by the research departments and universities in USA [6] and spread over to the world from that place. Internet has an indispensable position in the communication process in time thanks to its speed, reaching multiple targets and relatively low cost. Internet, which is being used in the trade, communication, education, entertainment and administration applications, has brought different daily living habits with it [7].

Rapid development of internet enables emerging of different dimension in the mass communication field as is in many other fields. Media is now assessed as two different groups such as traditional and new media.

While traditional media refers to mass communication tools such as newspaper, magazine, radio, television, the new media defines new communication environments in our life with internet technology.

New media concept, which has frequently been encountered in many studies in the field of communication recently, has been used by considering the transformation undergone by the communication technology. The audio, texts and visuals are in the same media in a digital format and they can be changed by reaching them interactively. The new media, of which the most distinct feature is to enable mutual interaction has another attention-grabbing feature, which is the richness of the content of the new media [34]. Such richness increases the influence of the new media on the young people and children. Such visuality stands out in the cyber social networks established in the new media. Social networks can be defined as the web page where new media users establish relations with each other through profiles created by them and create their own contents by making comments [32].

Social media, which enables its users to share information, opinions and fields of interests, has a structure to enable sharing of different perspectives and experiences. Besides all these features, the most distinctive feature of the social media is that its content is created by the user. The users with different field of interest can use social media thanks to the participation feature of the social media. Its structure, open to feedback, emphasizes its openness feature of the social media [34]. Participation and openness of the social media can positively affect the representation of the democratic societies in the new media. While people in the social media environments in new media can get into the act in different areas such as information gathering, entertainment, making friends, shopping and banking transactions, can be informed 
from different resources as required by the perspective of democratic governance and share their comments in different and free cyber media with other users [11]. Followings are the features of the social media where participation, interaction and sharing have been extensively carried out:

Rapid development of internet enables emerging of different dimension in the mass communication field as it is in many other fields. Media is now assessed as two different groups such as traditional and new media. While traditional media refers to mass communication tools such as newspaper, magazine, radio, television, the new media defines new communication environments in our life with internet technology.

New media concept, which has frequently been encountered in many studies in the field of communication recently, has been used by considering the transformation undergone by the communication technology. The audio, texts and visuals are in the same media in a digital format and they can be changed by reaching them interactively. The new media, of which the most distinct feature is to enable mutual interaction has another attention-grabbing feature, which is the richness of the content of the new media [34]. Such richness increases the influence of the new media on the young people and children. Such visuality stands out in the cyber social networks established in the new media. Social networks can be defined as the web page where new media users establish relations with each other through profiles created by them and create their own contents by making comments [32].

Social media, which enables its users to share information, opinions and fields of interests, has a structure to enable sharing of different perspectives and experiences. Besides all these features, the most distinctive feature of the social media is that its content is created by the user. The users with different field of interest can use social media thanks to the participation feature of the social media. Its structure, open to feedback, emphasizes its openness feature of the social media [34]. Participation and openness of the social media can positively affect the representation of the democratic societies in the new media. While people in the social media environments in new media can get into the act in different areas such as information gathering, entertainment, making friends, shopping and banking transactions, can be informed from different resources as required by the perspective of democratic governance and share their comments in different and free cyber media with other users [11]. Followings are the features of the social media where participation, interaction and sharing have been extensively carried out:

- Social media encourages its users.

- Social media enables fast and effective organization for communities. By this way, communities can share TV programs, political values, pictures of their choice.

- It enables individuals to make connections with relevant fields and matters of their interest.

- It enables everybody to reach an overall mass.

- Everybody can produce in social media without needing training or professionalism.
It can be updated all the time without time difference. Social media comments can be changed immediately by editing [33].

Facebook social share network, having all of the features of social media, draws the attention of the social media users with visual richness. It can be stated that visual richness of Facebook is an important factor for preference as it is used by the young population a lot. According to Turkish Statistical Institute 2014, internet use rate is $68.7 \%$ between 16 to 24 age ranges according to the age range of the individuals in Turkey. This rate reaches to $100 \%$ in (Denmark, Ireland, Finland, and Netherland, Norway) some countries according to the UNECE 2014 (United Nations Economic Commission for Europe) between the same age ranges. Social networks consist of different categories such as making friends and networks, social business networks, dating networks, graduate networks and brand social networks. Among these, Facebook, which is used to making friends and networks, has around 40 million users in Turkey [32].

Internet and social network, by which children have been, influenced more other than their families, school and friend groups have an undeniable role in development of ideological ideas that started to be shaped in political sense. The objective of this study is to examine the Facebook pages in Turkey, which have been prepared with content for children, which are at the beginning of the politicization process in consideration of the important position of the Facebook in the political communication process.

\section{Child, Social Media, Politics}

The concept of child has different meanings in the different periods of the history and several perspectives have been developed for the period of childhood representing the beginning of the socialization. The studies, which have been conducted on the history, have been added to the psychological, sociological and anthropological studies on the childhood in the last century. Historians have explained the lack of serious studies toward the childhood in the previous periods with the insufficient resources in this field [32]. It has been observed that there has been a different perspective on the child from middle ages to today. While children were not attached so much for they got sick and die in the middle age [33], in 16th an 17th century, it was thought that life should be dedicated to the education of the children. The opinions for the modern childhood were started to be created at the end of the 19th century and beginning of the 20th century [33]. Perspective on the child in the middle of the 20th century has changed a reflection of changing attitudes of the children. In this period, children know what they want more than their parents [33]. While the position of the child in the community life has been defined in 21 st century, the technological developments should be considered. Children can be influenced by the technological stimulus at all times and they spend more time on internet 
and on computer than those with family, school and friend circles. Having been influenced by an extensive information flow with internet, children keep off from some of the characteristics of childhood. The child, in the socialization process, starts to use information, got from the new media and mass media in the process of adapting to social life. The new media tools, covering most of the leisure time of the children, (computers, tablet computers, smart phones etc.) have a large impact in socialization [2].

Considering internet as a natural part of their lives, children are included to the political socialization process through internet and influenced from the political messages more with the effect of the rich visual presentation of internet content. As a result of the increasing time spend on the internet by the children, there are some initiatives, interested in the topic in a detailed and scientific manner; and some projects have been rolled out. As one of the projects, EU Kids Online Project [14] draws attention with its studies and reports. Covering many countries as to the cultural, contextual and dangerous circumstances for safe use of internet tools by the kids, this research project has been rolled out under the coordination of Dr. Sonia Livingstone and Dr Leslie Haddon from London School of Economics and Political Sciences (LSE) in 2006 (http://eukidsonline.metu.edu.tr/). The data in Turkey was collected in the May and June for the project. According to that, $45,9 \%$ of the children between 9-16 age ranges in Turkey started to use internet around 7-10 years old. $36,2 \%$ of the children use internet for one hour on average on a daily basis. Children use desktop computers, mobile phones and laptop computers to access internet. Furthermore, children access internet at 60,1\% from their schools and 51, 5\% from the internet cafe, not only from their homes. Most of the children, who are the internet users, have accounts in social network sites [34]. Children make friends, subscribe to the social groups and chat in these social networks and at the same time follow the content provided to them. This content can be game-entertainment, news-information and shopping and also contain political issues from time to time.

The importance of mass media tools for politics has gained a different dimension together with the emergence of the new media. Political content can be on the agenda without time and space with new media and reach to wider audience. Children institute the important part of this audience. Political authorities are aware that media can bring up issues to the agenda and enable actors of many systems to participate in the communication process at different rates [3]. New media has been started to be use more than the conventional media tools in the political communications. Political actors started to take part at every period of the political communication process not only for election periods in the new media. Social networks, contents of which are created by its users, become an important tool to reach target audience in the political communication process.

New media has been preferred in the political activities thanks to its structure to use services such as written communication, telephone communication, audio and visual mass media, information recording and storing, provided by the conventional media together. However, there are problems between new media and political relations such as easily changeable structure of the new media, not clearly defined resource and reliability problem, technical problems and insufficient knowledge of target audience [4].

While the relationship between new media and politics has been examined, the point to emphasize is that new applications brought to the democratic environment. NGOs can reach to the target audience with the help of the contents they create through new media. NGOs, one of the fundamental elements of democratic societies, use new media for express themselves and popularization. As a result of this, virtual communities have emerged through social media [1]. The children, active user of the social media, started to take the first messages as to the political socialization processes from these virtual networks. The children, who develop idea as to the political leaders, keep their first impressions on positive level with their robust impression skills until they become adults. After that they start to develop political motivations by knowing the political parties within their cognitive development process [32].

\subsection{Facebook and Children}

After introducing the effects of new media and social media especially on the political socialization processes of children, in this part of the study information will be given on the effects of Facebook social sharing network on children, studies carried out on Facebook usage by children, and respective family attitudes.

EU Kids Online, which performs surveys regarding the benefits and risks of Internet use by children aged 9-16, realized that the age of children using the Internet is dropping gradually and thus widened the scope of their research to also include children aged between 0-8. In these surveys, it was determined that children under the age of 9 engage in online activities; they are present in these environments to watch videos, play games, and look up information for their homework. On the other hand, participation of children in this age group in activities in the Internet environment, the fact that they have accounts in youth and adult-oriented social media networks (Facebook etc.), leads to debates concerning their safety on the Internet. Similarly surveys have revealed that in European countries like England, Finland, Spain, Germany, and France, children under the age of 13 have Facebook accounts and that Facebook is the most commonly used social sharing network by children [21].

Most of the research based on social media network use by children and youth is carried out in the framework of the subject of "safety", primarily oriented towards content that can be threatening to children. The main issues being discussed are safety measures that have to be taken when adjusting profile settings, the spreading of shared content among users, and the possibility of spreading of personal information in a similar way. 
Especially the personal information (name, surname, age, etc.), which mandatorily have to be provided when creating an account on the children's most preferred social sharing network, Facebook, can occasionally lead to safety problems in social sharing networks. In general, when we analyze youth's and children's Facebook accounts, we specifically find common features such as a friends list consisting of an average of 300 people, personal pictures, information about current school, and place of residence [24].

Social sharing networks, the use of which have now become a common daily life activity for children, are regarded in a sense as communication environments. Children who communicate with their classmates in these environments also communicate with unfamiliar people through their shared content. Access to social sharing network accounts, which are being checked occasionally during the day, has started to become unavoidable with the aid of smartphones. Social sharing networks, which are evaluated based on negative aspects such as security issues and abuse, can be also evaluated based on their contribution to communication and the convenience they provide in terms of obtaining information [25].

Social sharing networks also grew stronger in the field of politics by expanding and thus reaching a great number of users, and through their frameworks that enable sharing and communication. Among other social sharing networks, Facebook has drawn the interest also of those interested in the subject of politics, owing to features including a large number of users, suitability to create different profiles based on geographical regions, and the enabling of easy access to personal information of users [34].

Social sharing networks and particularly Facebook have in a sense started to challenge traditional ways used in political activities. In this respect, social sharing networks acquired an important role especially in political socialization. This is also because they support social movements and are tools that enable the spread of ideas and social engagement [5]. Community pages created with political content in the Facebook social sharing network, invite additional new members to adopt their ideology through their ideological messages. Children who are in the beginning of the political socialization process constitute an important target group to which these messages are planned to be conveyed.

In this study, 4 community pages, having political content, have been selected to be examined among the community pages created in the Facebook social network by using child key word. Political messages, delivered in these community pages, where attractive visuals, videos are prepared and used for children, will be examined with the semiotic analysis.

\section{Methodology and Results}

It is not possible to mention a single theory on the semiotics, which was developed in 1960's and popularized. Saussure and Peirce are the two important people standing out at the end of the 19th century and in the beginning of the 20th century for the semiotic studies. Having defined sign as anything which is so determined by something else, called its object, and so determines an effect upon a person, which effect he calls its interpretant, that the latter is thereby mediately determined by the former, Peirce upholds that semiotics is a science basing on the logic. Founder of linguistics, Saussure defines semiotics as the science examining the lives of signs within the community. Maintaining his studies after Saussure and Peirce, Barthes presents a set of wide range of sings as an examination object of semiotics [34].

Semiotics, defined by Pierre Guiraud as examination of non-linguistic signs [33] has been used with sign category, which has been conducted basing on the relationship between the object signed and reference by the Peirce. Peirce considers sign, reference of sign and user of sign as the corners of a triangle [34]. Being a keyword in semiotics, sign enables communication by referencing an object even though it is not an object and is everything that represents other things. To Parsa, a sign can be a word, audio or visual image [32].

In this study, visual semiotics, which has been emerged as a new branch of the semiotics in 1990's, is of importance. The meaning and ideological factors of the content of the texts on which visual signs are predominant in the visual semiotics in line with the importance of the non-verbal semiotics in the communication process have been analyzed [28]. It is necessary to present and construe the meaning of the semiotic signs and relationship with other signs to analyze the signs in the visual semiotics [32].

The distinction between the denotation and connotation used by the Barthes has been considered in semiotic sense making in this study. While denotation refers to same conclusion by everyone who conducts sense making, connotation is associated with the emotions, excitements and cultural values arise by the sign in the interpreter. Connotation presents the difference in the sense making. Connotation, which is specific to culture, can be shared by the community [32]. According to the sign diagram of Barthes, as the form is transferred by the signifier, content is transferred by the signified. Facebook social network ideological tendencies for children have been assessed with the help of the tables in the scope of the sign-signifier-signified relationship.

4 pages, among the pages, considering the number of the followers/likes in the search results of the community pages used by child key word in the Facebook among other social networks in the new media has been examined to specify their ideological tendencies through semiotic analysis method. According to that, community pages, created with such content in Facebook are Çocuk Olmak (Being Child), Çocuk Cezaevleri Kapatılsın Girişimi (Initiative to Close Juvenile Detention Centers), Çocuk Hakları (Children Rights) and Çocuk Sayfası (Child Page) as a result of the research made on the date of September 2015.

Çocuk Olmak community page is liked/followed by the 21,995 people. Visual content has been used mostly in the page created in September 2009. The words of the page such 
as peace, war, poverty, death, labor, revolution, siege, detention camp, salvation have been repeated frequently. These words are used with the poems together with the children pictures and texts written by the page administrator.

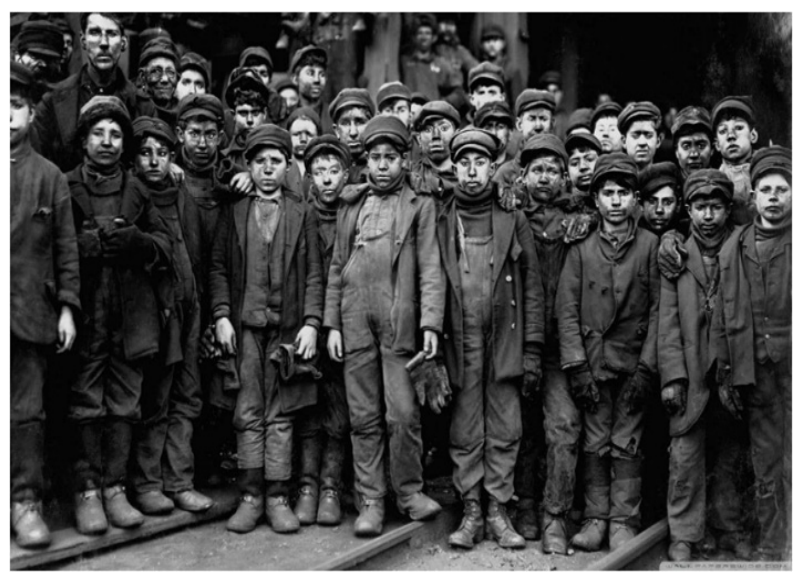

Figure 1. "Çocuk Olmak" Facebook Community Page

Table 1. Çocuk Olmak Facebook Community Page Ind. Analysis

\begin{tabular}{|c|c|}
\hline Indicator & "Çocuk Olmak" Facebook community page photo \\
\hline Indicative & Boys ranked on the train tracks in the working clothes \\
\hline Indicated & $\begin{array}{c}\text { Anxiety and desperation of the school age children } \\
\text { working }\end{array}$ \\
\hline
\end{tabular}

Critical structure of socialism on the capitalism, which started to form in the second half of the 18th century of the industrial community [33], draws attention as well in the example above as it is in overall of the Çocuk Olmak community page. Using the words of Karl Marx in the text of the visual proves that.

Another page is Çocuk Cezaevleri Kapatılsın Girişimi) Initiative to Close Juvenile Detention Centers) Page which has been liked/followed by 7466 people, created in May 2014. The page expresses that the page has been created with an association of human rights and child rights organization claiming to close the juvenile detention centers and end juvenile detention, which has been formed in January 2014.

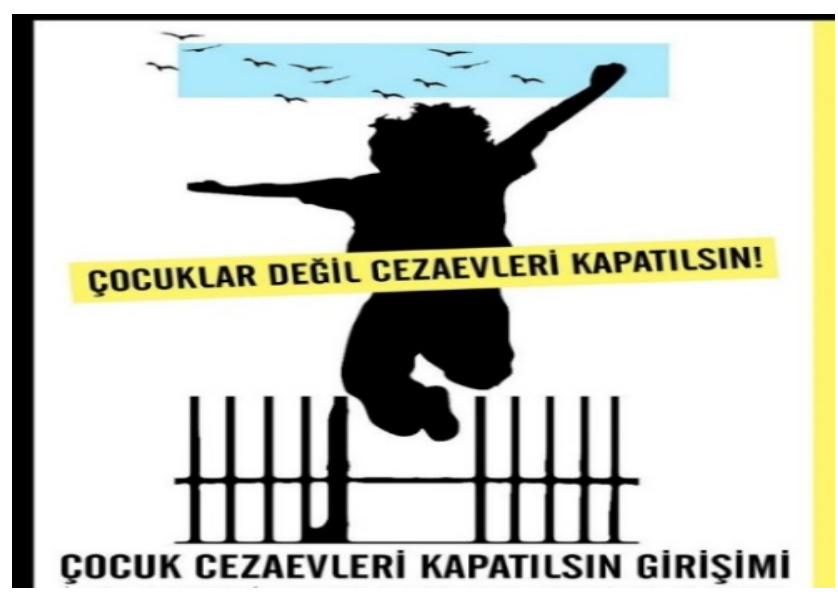

Figure 2. "Çocuk Cezaevleri Kapatılsın Girişimi” Facebook Community Page.
Table 2. "Çocuk Cezaevleri Kapatılsın Girişimi” Facebook Community Page. Ind. Analysis

\begin{tabular}{|c|c|}
\hline Indicator & $\begin{array}{r}\text { Çocuk Cezaevleri Kapatılsın Girişimi Facebook } \\
\text { Community Page profile photo }\end{array}$ \\
\hline Indicative & Image of boy jumping over a fence \\
\hline Indicated & $\begin{array}{c}\text { A little boy flying like freedom birds freed from } \\
\text { captivity by jumping over the prison fence }\end{array}$ \\
\hline
\end{tabular}

We can set Çocuk Cezaevleri Kapatılsın Girişimi Facebook community page as an example for freedom to create and share content of the social media as specified at the beginning of the study. The page emphasizes the critical approach to the keeping the children in captivity, which has been created as a civil society movement with its significant role of social media in the democratic communities.

Cocuk Sayfası was created in May 2010 and liked/followed by 5102 people. Animal images and baby pictures have been used in the Çocuk Sayfası as different from the other community pages. Another attention grabbing point in the page, in which entertainment function has been emphasized, is that it gives links to other child web pages with different names. Religious motives have been used and hadith and verse of the Koran have been given as an example.

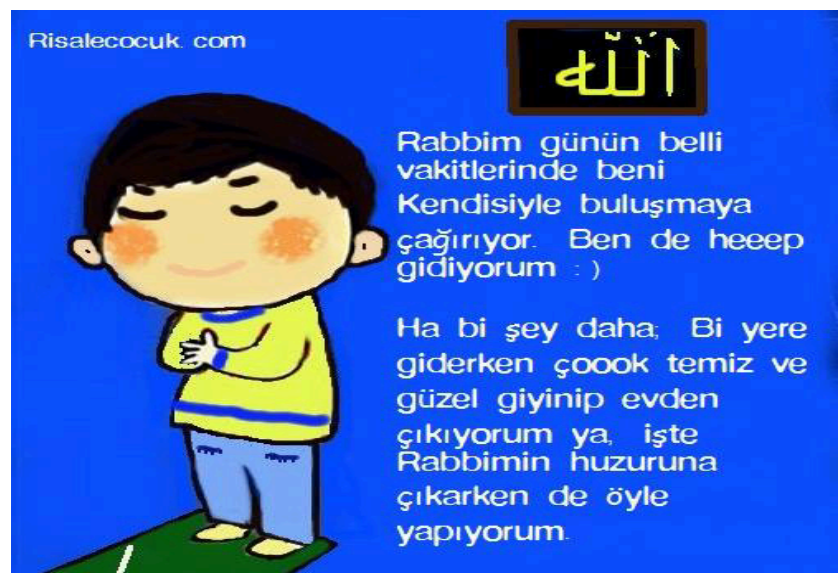

Figure 3. "Çocuk Sayfası" Facebook Comm. Page

A child has been drawn in the image as performing salaat and it is specified that being clean is required by the religion as performing salaat is to meet with Allah. Smile and peace expression in the face of the boy performing salaat is clearly specified in the drawing.

Table 3. "Çocuk Sayfası” Ind. Analysis

\begin{tabular}{|c|c|}
\hline Indicator & Facebook profile photo of "child page" \\
\hline Indicative & The boy praying \\
\hline Indicated & $\begin{array}{c}\text { The boy meets with a smile on his face and prayed God } \\
\text { is for peaceful worship. }\end{array}$ \\
\hline
\end{tabular}

As we can understand from the name of the Çocuk Hakları (Children Rights) Facebook community page, liked/followed by 118 people already and created in March 2014 , it aims to draw attention to all abuses against the children. The other pages, which have been used, depict violence, blood and hunger with all explicitness. These 
images, negatively influencing the children followers, are supported with texts defending the children rights.

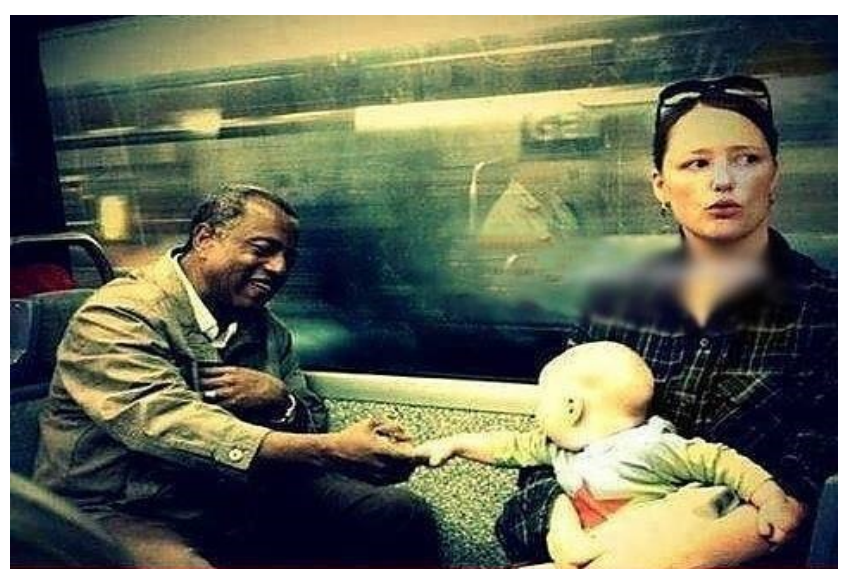

Figure 4. "Çocuk Hakları" Facebook Comm.Page

Table 4. “Çocuk Hakları” Ind. Analysis

\begin{tabular}{|c|c|}
\hline Gösterge & Profile photo of "Çocuk Hakları" page \\
\hline Gösteren & Mother traveling on the subway with her baby and a \\
black guy
\end{tabular}

\section{Conclusions}

In this study, the ideological elements that are prepared with children-oriented content and that are found in social media content, which children can easily access through new media, are investigated with a semiotic analysis method. The exemplary Facebook community pages selected in terms of children rights, child abuse, violence against children, child poverty, and religious elements, were observed to communicate these subjects with their followers by sharing striking visuals. However, there is disharmony between ideas and practice in the majority of the pages that adopt a protective attitude towards children. It is inevitable that children who are at playing age will be psychologically negatively affected when they come across such content. Similarly, the sharing of political messages intensely will influence children who are at the outset of the socialization process. In our day when all social media users are also content creators as media authors regarding content sharing, it is necessary to create a balance between the protective attitude that tries to protect children from media's negative effects and the attitude that tries to show facts without any restriction. This necessity can be indicated as the outcome of this study. Instead of a merely critical or merely protective-controlling attitude, an attitude, which can reflect clearly the difference between the right and the wrong, will eliminate the vulnerability of children in social sharing networks. Handling media content in terms of its benefits instead of approaching it with a skeptical attitude will ensure that positive results are obtained. Media content also contains very useful information for personal development; this information should be turned to advantage for personal development.

In our day, social sharing networks are of the most important resources where children can obtain information about the world. Being easily accessible and not being faced with the barriers of time and space, makes the Internet and thus social sharing networks much more prominent compared to other communication channels. Another finding of the study that has to be emphasized is that in spite of all these features of social sharing networks, there is a need to make a set of regulations for media training. Thus children who will learn to read and evaluate media messages with a much more comprehensive perspective, will exhibit a more conscious attitude towards the media content that they encounter. If media training is carried out by professionals who have a good command of the subject, media content including ideological messages can be evaluated with a different perspective.

\section{REFERENCES}

[1] Akbaş, M. İnternet iletişimi ve demokrasi. İstanbul Üniversitesi İletişim Fakültesi Dergisi, 18, s.177-202, 2003.

[2] Akçalı,İ.S. Çocuk ve Medya. Ebabil, Ankara, 2007.

[3] Alver, F. Medya ve politika. İstanbul Üniversitesi İletişim Fakültesi Dergisi,7,39-52, 1998.

[4] Aziz, A.Siyasette Etkili İletişim Teknikleri. Başlık, İstanbul, 2011.

[5] Crivellaro, C., Comber, R., Bowers, J., Wright, P. C., \& Olivier, P. A pool of dreams: Facebook, politics and the emergence of a social movement. In Proceedings of the SIGCHI Conference on Human Factors in Computing Systems, 3573-3582, 2014.

[6] Cohen, R. Internet history. International Journal of Technoethics, 2, 45-64, 2011.

[7] Çakır, H. Topçu, H. Bir iletişim dili olarak internet.Erciyes Üniversitesi Sosyal Bilimler Enstitüsü Dergisi, 19, 71-96, 2005.

[8] Çocuk Cezaevleri Kapatılsın Girişimi (Initiative to Close Juvenile Detention Centers): Online available from:https://trtr.facebook.com/cocukcezaevlerikapatilsin.

[9] Çocuk Olmak (Being Child) Facebook Community Page: Online available from:https://www.facebook.com/CocukOl/

[10] Çocuk Sayfası (Child Page) Facebook Community Page: Online available from: https://tr-tr.facebook.com/CocukSayf asi.

[11] Çulha, O.Göstergebilim tekniği kullanarak kanada fotoğraflarının incelenmesi. ZKÜ Sosyal Bilimler Dergisi, 7, 409-424, 2011.

[12] EU Kids Online, Online available from 
http://eukidsonline.metu.edu.tr/.

[13] Fiske, J. İletişim Çalışmalarına Giriş, Süleyman İrvan (Çev.) Bilim ve Sanat, Ankara, 1996.

[14] Gezgin, S. Medya ve demokrasi, 20.Alman-Türk Gazeteciler Sunumlar1, Online available from http://www.kas.de/proj/ho me/pub/44/2/year-2007/dokument_id-9459/index.html.

[15] Giddens, A. Üçüncü Yol Sosyal Demokrasinin Yeniden Dirilişi, Mehmet Özay (Çev.). Birey, İstanbul, 2000.

[16] Global Social Digital, Online available from http://etonprene urs.com/uploads/Global\%20Social,\%20Digital\%20\&\%20M obile\%20Statistics,\%20Jan\%202014.pdf,2014

[17] Greenberg, E. Political Socialization. Atherton, New York, 2009.

[18] Guiraud, P. Göstergebilim, Mehmet Yalçın (Çev.). Ankara:İmge, Ankara, 1994.

[19] Gümüş, K. Şahin, H. Temel göstergebilim kavramları. Mimarlık, 11, 35-37, 1982.

[20] Hazar, M. Sosyal medya bağımlılı̆̆ı. İletişim Kuram ve Araştırmaları Dergisi, 32, 151-175, 2011.

[21] Heywood, C.. Batı'da Çocukluğun Tarihi, Esin Hoşsucu (Çev.). İstanbul: Kitap, İstanbul, 2003.

[22] Holloway, D., Green, L., Livingstone, S. Zero to Eight Young Children and Their Internet Use. Online available from http://eprints.lse.ac.uk/52630/1/Zero_to_eight.pdf

[23] Kaşıkçı, D., Çağıltay,K., Karakuş, T., Kurşun, E, Ogan, C. Türkiye'deki ve Avrupa'daki çocukların internet alışkanlıkları ve güvenli internet kullanımı, Eğitim ve Bilim, 171, 230-243, 2014.

[24] Mause L., The History of Childhood. The Rowman and Littlefield, USA, 2006.
[25] Madden, M., Lenhart, A., Cortesi, S., Gasser, U., Duggan, M., Smith, A., Beaton, M. Teens, Social Media and Privacy. Online available fromhttp://www.pewinternet.org/2013/05/2 1/teens-social-media-and-privacy/

[26] O'Keeffe, G. S. Clinical report - the 1mpact of social media on children, adolescents, and families. Pediatrics, 127, 800-84, 2011.

[27] Onur, B. Anılardaki Aşklar: Çocukluğun ve Gençliğin Psikoseksüel Tarihi, Kitap, İstanbul, 2005.

[28] Öztürk, S. En eski ve en yeni iletişim medyası: insan. Praksis, 24, 115-132, 2010.

[29] Parsa, A. F. Göstergenin Gücü/Gücün Göstergesi: İmge Reklam Bildirilerinde Göstergebilimsel Yaklaşımla Durağan İmgeleri Çözümlemek. Online available from http://aisv2007.zxq.net/4GUN/4ANFI_B/4ALEV_F_PARS A.pdf.

[30] Pollock, L. Forgotten Children, Cambridge University. Postman, N. (1995). Cocukluğun Yokoluşu,Kemal İnal (Çev.). İmge, Ankara, 1996.

[31] Solmaz, B., Tekin, G., Herzem, Z., Demir, M.,Internet ve sosyal medya kullanımı üzerine bir uygulama. Selçuk İletişim, 7, 25-32, 2013

[32] Topçu, A.D. Kayseri'yi okumak: göstergebilimsel yaklaşımla bir şehrin analizi, Erciyes Üniversitesi Sosyal Bilimler Enstitüsü Dergisi, 18, 237-246, 2005.

[33] Vural, B., Bat, M. Yeni bir iletișim ortamı olarak sosyal medya: ege üniversitesi iletişim fakültesine yönelik olarak bir çalışma, Journal of Yasar University, 3348-3382, 2010.

[34] Webrazzi, Online available from, http://webrazzi.com/2015/ 09/03/facebook-turkiye-aylik-kullanici-sayisi.

[35] Wills, D. Reeves, S. Facebook as a political weapon: Information in Social Networks, 4, 265-281, 2009. 